\title{
F7 wt Allele
}

National Cancer Institute

\section{Source}

National Cancer Institute. F7 wt Allele. NCI Thesaurus. Code C51234.

Human F7 wild-type allele is located within $13 q 34$ and is approximately 14 kb in length.

This allele, which encodes coagulation factor VII protein, plays a role in homeostasis and blood coagulation. Defects in the gene associated with variant alleles are causative agents for coagulopathy. 